\title{
Postrzeganie dźwięków otoczenia w subiektywnej ocenie użytkowników implantów ślimakowych przed aktywacją i po aktywacji systemu implantu ślimakowego
}

\section{Perception of ambient sound in the subjective assessment of cochlear implant users before activation and after activation of the cochlear implants system}

\author{
Anna Obszańska, Artur Lorens, Tomasz Wiśniewski, Agata Lutek, Aleksandra Pieczykolan, \\ Henryk Skarżyński
}

Instytut Fizjologii i Patologii Słuchu, Światowe Centrum Słuchu, Warszawa/Kajetany

Adres autora: Anna Obszańska, Światowe Centrum Słuchu, Zakład Implantów i Percepcji Słuchowej, ul. Mokra 17, Kajetany, 05-830 Nadarzyn, e-mail: a.obszanska@ifps.org.pl

\section{Streszczenie}

Wstęp: Dźwięk, jako zdarzenie rozpatrywane holistycznie, jest istotny dla odbioru krajobrazu środowiskowego. Głęboki ubytek słuchu, ograniczając możliwość percepcji dźwięków otoczenia w pełnym zakresie częstotliwości, wpływa na jakość życia osób z wadą słuchu, ogranicza ich możliwość całkowitego włączenia się w środowisko i pełnienie ról społecznych. System implantu ślimakowego (CI) jako medyczny środek rehabilitacyjny kompensujący ubytek słuchu poprawia postrzeganie dźwięków i prowadzi do zmniejszenia skutków niepełnosprawności.

Cel: Analiza subiektywnej oceny postrzegania dźwięków otoczenia dokonanej przez użytkowników CI.

Materiał i metody: Badania kwestionariuszowe przeprowadzono wśród 88 dorosłych pacjentów przed aktywacją CI i po miesiącu korzystania z niego oraz w grupie 43 osób dorosłych ze słuchem prawidłowym. Posłużono się kwestionariuszem „Karta dźwięków", opracowanym w Zakładzie Implantów i Percepcji Słuchowej dla pacjentów z CI.

Wyniki: Przed aktywacją CI pacjenci z prezentowanych w kwestionariuszu dźwięków otoczenia nie odbierali średnio 31,7\% tych dźwięków. Miesiąc po aktywacji CI wartość ta zmniejszyła się do 15,9\%. Przed aktywacją CI 29,8\% pacjentów słyszało mniej niż 43\% dźwięków, zaś $24,1 \%$ pacjentów słyszało co najmniej $86 \%$ dźwięków. Miesiąc po aktywacji ponad $90 \%$ pacjentów słyszało co najmniej $43 \%$ dźwięków. Natomiast 35,6\% wszystkich badanych słyszało co najmniej 86\% dźwięków. Przed aktywacją CI dźwięki, które najrzadziej były odbierane przez pacjentów jako nieprzyjemne, to: cięcie papieru, odgłos kierunkowskazu oraz szum gotującej się wody. Natomiast za najbardziej nieprzyjemne uznali oni: hałas uliczny, szelest reklamówki i odgłos sztućców.

Po aktywacji CI do najmniej nieprzyjemnych dźwięków pacjenci zaliczyli: odgłos kierunkowskazu, śpiew ptaków oraz tykanie zegara. Z kolei wśród najbardziej nieprzyjemnych dźwięków odbieranych w miesiąc po aktywacji CI wymieniane były: pisk opon, karetka pogotowia i odgłos sztućców.

Wnioski: Przed aktywacją CI większość pacjentów zgłaszała postrzeganie blisko połowy wymienionych w kwestionariuszu dźwięków otoczenia. Po upływie zaledwie miesiąca od aktywacji CI postrzeganie to uległo istotnej statystycznie poprawie. Po porównaniu okresu przed wszczepieniem CI z okresem po aktywacji urządzenia stwierdzono, że efekt estetyczny tych dźwięków nie pogorszył się. Ocena estetyki w odniesieniu do kategorii przyjemny/nieprzyjemny była podobna u osób implantowanych i osób ze słuchem prawidłowym.

Słowa kluczowe: dźwięki otoczenia • pacjent z systemem implantu ślimakowego • percepcja • efekt estetyczny dźwięku (przyjemny/nieprzyjemny) • niepełnosprawność • jakość życia 


\section{Abstract}

Introduction: A Sound, understood holistically, is a crucial element in the perception of environment. Profound hearing loss, as it results in inability to perceive the full range of the environmental sounds, has a significant influence on the quality of life of deaf individuals, reducing their chance to take part in life and fulfill their social roles. A cochlear implant system (CI), as a hearing prosthesis device, helps to improve the perception of sounds and reduce the impairment effects.

Aim: To analyze the subjective assessment of the environmental sound perception of cochlear implant users.

Material and methods: This study was performed in a group of 88 adult patients before the CI activation and one month after the activation, and in a group of 43 adults with normal hearing. The study used the 'Sound Chart' questionnaire created in the Implants and Auditory Perception Department for CI users.

Results: Before the activation of the CI, patients did not hear $31.7 \%$ of sounds in avarage. One month after the activation this value decreased by half, to $15.9 \%$. One month after the CI activation $90 \%$ of patients heard less than $43 \%$ of sounds and $35.6 \%$ heard at least $86 \%$ of sounds.

Before the CI activation, sounds which were the least often perceived by participants of the study as unpleasant were: cutting paper, the sound of a blinker and boiling water. The most unpleasant sounds were: street noise, the rustle of a plastic bag, the sound of cutlery.

After the activation the least unpleasant sounds were: the sound of a blinker, voices of birds and clock ticking. Whereas the most unpleasant were: the screech of tires, the emergency car signal and the sound of cutlery one month after the activation.

Conclusions: Before the CI activation, most patients reported the perception of almost half of the listed environmental sounds. One month after the activation, their perception improved in a statistically relevant way. After the activation the aesthetic effect of these sounds was not worsened compared to the period before cochlear implantation. The aesthetic assessment of sounds in terms or pleasant/unpleasant by the CI users and people with normal hearing was similar.

Key words: environmental sounds $\bullet$ cochlear implant user • perception • aesthetic effect of sound (pleasant/unpleasant) • impairment $\bullet$ quality of life

\section{Wstęp}

Dźwięk będący przedmiotem zainteresowania specjalistów $\mathrm{z}$ wielu różnych dziedzin nauki, m.in. akustyki, antropologii kulturowej, architektury krajobrazu, etnologii, estetyki, geografii, medycyny, muzykologii, psychologii, socjologii, urbanistyki, jest przez nich odmiennie definiowany [1]. Dźwięk w akustyce określany jest jako zaburzenie falowe rozchodzące się w powietrzu, związane $\mathrm{z}$ drganiami akustycznymi, będące w stanie wytworzyć u człowieka wrażenia słuchowe [2]. W psychoakustyce - dziale psychologii eksperymentalnej - dźwięk to wrażenie słuchowe, dzięki któremu tworzone jest mentalne odzwierciedlenie otoczenia [3]. Naukowcy, którzy prowadzą badania nad percepcją otoczenia i chcą opisać zjawiska związane z dźwiękiem, posługują się różnymi określeniami, takimi jak np. fonosfera, audiosfera, melosfera, sonosfera, krajobraz dźwiękowy, pejzaż dźwiękowy, krajobraz akustyczny, pejzaż akustyczny, przestrzeń dźwiękowa, przestrzeń akustyczna, przestrzeń foniczna, warstwa dźwiękowa krajobrazu czy też klimat akustyczny $[1,4]$.

Dźwięki otoczenia definiowane są w literaturze przedmiotu jako dźwięki generowane przez realne zdarzenia, np. szczekanie psa [5], nie muszą być natomiast nośnikiem znaczenia [6]. W literaturze zagranicznej dźwięki otoczenia są określane jako: ambient sounds, environmental sounds, nonlinquistic sounds, everyday sounds, natural sounds, nonverbal sounds, familiar environmental sounds, background sounds, naturally-occurring sounds [6-11].
Niektórzy badacze do dźwięków otoczenia zaliczają także muzykę [12]. Inni z kolei uważają ją za odrębną kategorię dźwięków, zastrzegając, że dźwięki otoczenia to te, które występują naturalnie i są niewerbalne oraz niemuzyczne, czyli pozbawione ustrukturalizowanej formy językowej, a w celu identyfikacji dźwięku poszukuje się ich źródła [10].

Granica między dźwiękami mowy a dźwiękami środowiska jest nieco niejasna $-\mathrm{z}$ jednej strony niektóre $\mathrm{z}$ nich, jak np. płacz dziecka, mogą być traktowane jako protomowa, z drugiej - występuje wiele „nieludzkich” źródeł dźwięku, które posiadają funkcję komunikacyjną (syreny, gwizdki, klaksony samochodów) [10]. Dlatego też nazewnictwo dźwięków otoczenia w przeanalizowanej literaturze przedmiotu różni się.

Zdaniem Tylera i współautorów [7] do dźwięków otoczenia zaliczyć można: muzykę, dzwonek do drzwi, sygnały ostrzegawcze, dzwonek telefonu, śpiew ptaków. Autorzy wyróżniają również kategorię nieprzyjemnych dźwięków otoczenia, których źródłem jest np. wiatr, samolot, wypadek, lejąca się woda. W artykule Lewisa [13] do grupy dźwięków środowiskowych zaliczane są również odgłosy narzędzi, zwierząt, płynów, drobnych obiektów. Z kolei Goldhor w tej grupie wymienia dźwięki domowe, biurowe i te „zewnętrzne” [11]. Reed rozszerza nieco tę kategorię o dźwięki ogólnie domowe, kuchenne, biurowe i także „zewnętrzne” [14]. 
Test wykorzystywany w Instytucie Fizjologii i Patologii Słuchu do oceny postępów słuchowych u dzieci i osób dorosłych korzystających z aparatów słuchowych i implantów składa się z dwunastu dźwięków otoczenia. Wśród nich są dźwięki, których źródłem są: pojazdy, zwierzęta, przyroda, instrumenty, czynności, ludzie.

W dalszej części artykułu w odniesieniu do dźwięków otoczenia używane będzie sformułowanie „krajobraz dźwiękowy”. Krajobraz dźwiękowy jest kształtowany przez dźwięki należące do rozmaitych kategorii: naturalne odgłosy przyrody, dźwiękowe oznaki produkcyjnej działalności człowieka (np. hałas pracujących urządzeń technicznych), dźwięki powstałe w wyniku artystycznej działalności człowieka (np. muzyka), dźwięki będące obiektami semiotycznymi, czyli komunikujące treści (np. sygnał karetki), oraz dźwięki mowy ludzkiej [1]. Dźwięki otoczenia pełnią różne funkcje - są między innymi nośnikiem informacji w przestrzeni o elementach ją wypełniających oraz zachodzących w niej procesach i zjawiskach, pozwalają zatem przeżyć, wzbogacają życie i spełniają rolę kulturotwórczą [16]. Kowalczyk uszczegóławia te funkcje, dzieląc je na: ostrzegawcze, towarzyszące, orientacyjne, ochronne, relaksujące, stresujące i monitorujące [16].

Dźwięk w otoczeniu uważany jest za jeden z najbardziej intensywnych bodźców, będący ważnym składnikiem doznań emocjonalnych, w tym również przeżyć estetycznych [12]. Zdarzenia akustyczne mogą wywoływać poczucie przyjemności bądź dyskomfortu [17]. Różne dźwięki są oceniane jako bardziej lub mniej przyjemne. Krajobraz dźwiękowy jest także źródłem dźwięków nieprzyjemnych, a zatem takich, które budzą lęk, są uciążliwe dla zdrowia fizycznego i psychicznego lub wywołują przykre wspomnienia. Dźwięki w krajobrazie mogą informować o niebezpieczeństwie, powodować nieprzyjemne skojarzenia oraz mogą być przykre ze względu na brak porządku i harmonii lub nadmierne natężenie (hałas) [16]. Oddziałują $\mathrm{w}$ ten sposób na psychikę odbiorcy, istotnie wpływając na odczuwaną przez niego jakość życia [12].

Percepcja jest procesem twórczym, polegającym na aktywnym odbiorze, analizie oraz interpretacji zjawisk zmysłowych. W procesie postrzegania dźwięku sygnały są przetwarzane $\mathrm{w}$ sposób zgodny $\mathrm{z}$ nabytym wcześniej doświadczeniem [1], a zatem jest to aktywność zindywidualizowana, zależna od możliwości postrzegania [18]. Postrzeganie jest rozumiane w niniejszej pracy jako możliwość słyszenia dźwięku oraz określenie doznań estetycznych z nim związanych w kategorii przyjemny/nieprzyjemny.

Osoba $\mathrm{z}$ prawidłowym słuchem dźwięki ciche odbiera tak samo dobrze jak głośne, ale w subiektywny sposób będzie interpretować oraz kształtować swoje postrzeganie krajobrazu dźwiękowego. Natomiast niedosłuch może znacząco ograniczyć percepcję dźwięków otoczenia. Słuchanie dźwiękowego tła pozwala na określenie własnego stosunku do konkretnego miejsca o charakterze fizykalnym, natomiast ograniczenie w słyszeniu dźwięków może powodować zaburzenie szeroko rozumianej orientacji w przestrzeni [6]. Słuch, według badań etnomuzykologa Stefana Felda, jest najważniejszym zmysłem u człowieka w sensie kulturowym, gdyż jest on odpowiedzialny za tworzenie relacji społecznych i struktur organizujących emocje [16]. Jego dysfunkcja równoznaczna jest zatem z problemami w komunikacji międzyludzkiej, co niekiedy może prowadzić nawet do wykluczenia ze społeczeństwa [18]. Wiele osób dotkniętych uszkodzeniami słuchu odczuwa wyobcowanie i niezrozumienie ze strony otoczenia, czego skutkiem jest obniżenie jakości życia tych osób, a także znaczące zmniejszenie poczucia szczęścia, czyli tzw. „dobrostanu” [19].

Obecnie istnieją możliwości kompensacji ubytków słuchu na drodze operacyjnej lub przy użyciu medycznego środka rehabilitacyjnego. Medyczne środki rehabilitacyjne są dobierane odpowiednio do rodzaju niedosłuchu i znacząco wpływają na poprawę sytuacji osób niedosłyszących. W przypadku niedosłuchu zmysłowo-nerwowego konieczne jest niekiedy zastosowanie systemu implantu ślimakowego [20]. Tę metodę leczenia wprowadził w Polsce H. Skarżyński.

Literatura dotycząca korzyści z CI, jakie czerpią użytkownicy tego urządzenia, jest bardzo bogata, ale głównie skoncentrowana na poprawie dyskryminacji dźwięków mowy. $\mathrm{Z}$ nielicznych badań nad postrzeganiem dźwięków otoczenia przez osoby korzystające z CI wynika, że możliwość odbioru dźwięków otoczenia ma istotne znaczenie dla jakości ich życia.

Wyniki badań Tylera dotyczące skuteczności stosowania implantów ślimakowych wykazują, że 75\% badanych uznaje, iż postrzeganie dźwięków otoczenia jest bardzo ważne ze względu na wynikające $\mathrm{z}$ tego tytułu korzyści, dotyczące w głównej mierze aspektu psychologicznego - poczucia jedności z otaczającym środowiskiem, a co za tym idzie zwiększenia poczucia bezpieczeństwa. Poprawa słyszenia, w tym także odbioru dźwięków otoczenia, doprowadziła do poprawy jakości życia [7].

Zhao dowodzi, że system implantu ślimakowego przyczynia się do redukcji skutków niepełnosprawności, a tym samym do poprawy jakości życia, na co mają wpływ postrzeganie dźwięków otoczenia, subiektywnie odczuwalne polepszenie komunikacji i związany $\mathrm{z}$ tym wzrost poczucia pewności siebie [21].

W opinii Reeda - pacjenci mający możliwość odbioru dźwięków otoczenia są włączeni w otaczający ich świat, mają poczucie bycia w kontakcie, a nie izolacji, co daje im możliwość podejmowania różnych aktywności w codziennym funkcjonowaniu i tym samym zwiększa ich jakość życia [14].

Istnieją ponadto liczne badania, w których uznaje się, że postrzeganie czy identyfikowanie dźwięków otoczenia ma wpływ na lepsze rozpoznawanie mowy [10,14,22-24], jak również badania przeciwstawiające się tej tezie [25,27].

\section{Cel}

Celem pracy była analiza subiektywnej oceny postrzegania dźwięków otoczenia dokonanej przez użytkowników implantów ślimakowych. 


\section{Materiał i metoda}

Metodą badawczą użytą w niniejszej pracy był sondaż diagnostyczny, wykorzystywany w badaniach ilościowych. Technikę tę zastosowano w celu poznania opinii badanej grupy, tak aby uzyskane dane przedstawić numerycznie dla wyjaśnienia zmian zachodzących po aktywacji systemu implantu ślimakowego. Wykorzystano kwestionariusz ankiety $\mathrm{z}$ kafeterią zamkniętą, z użyciem pytań alternatywnych [26-29].

Kwestionariusz ankiety „Karta dźwięków” został opracowany w Zakładzie Implantów i Percepcji Słuchowej na podstawie testu SERT ${ }^{1}$ [30]. Ankieta zawiera dwa pytania zamknięte dotyczące postrzegania 21 dźwięków otoczenia ułożonych losowo (odkurzacz, śpiew ptaków, odgłos sztućców, samolot, suszarka do włosów, woda płynąca z kranu, sygnał karetki pogotowia, płacz dziecka, burza $\mathrm{z}$ piorunami, szelest reklamówki, tykanie zegara, czajnik z gwizdkiem, spuszczanie wody w toalecie, stukanie obcasów, hamowanie/pisk opon samochodu, szelest kartek papieru, szczekanie psa, cięcie papieru nożyczkami, hałas uliczny, odgłos kierunkowskazu w samochodzie, szum gotującej się wody). W pierwszym pytaniu pacjenci udzielali odpowiedzi, czy słyszą każdy z dźwięków. Możliwe były odpowiedzi: „tak”, „nie”, „nie miałem(am) okazji sprawdzić”. Jeśli odpowiedź na pierwsze pytanie była twierdząca, pacjent miał zaznaczyć, czy dany dźwięk jest dla niego nieprzyjemny - możliwe były odpowiedzi „tak” albo „nie”.

Kwestionariusz ankiety wydano dorosłym pacjentom Instytutu Fizjologii i Patologii Słuchu z niedosłuchem zmysłowo-nerwowym, którym w okresie od maja do października 2014 r. aktywowano CI. Badaniami objęto wszystkich, którzy prawidłowo wypełnili kwestionariusz, czyli 88 osób (46 kobiet i 42 mężczyzn), w wieku od 18 do 77 roku życia (średnia wieku 47,6 lat), co stanowi 97\% pacjentów z tego okresu. Pacjenci korzystali z implantów ślimakowych firm Med-El, Cochlear i Advanced Bionics. Charakterystykę grupy przedstawiono na rycinach 1 i 2 .

Podział osób badanych ze względu na wartości audiometryczne przedoperacyjnych progów słyszenia w uchu o lepszej czułości słuchu przedstawiono na rycinie 3. Podział ten został dokonany zgodnie z klasyfikacją PDT według Skarżyńskiego [20,25] przedstawioną na rycinie 4 .

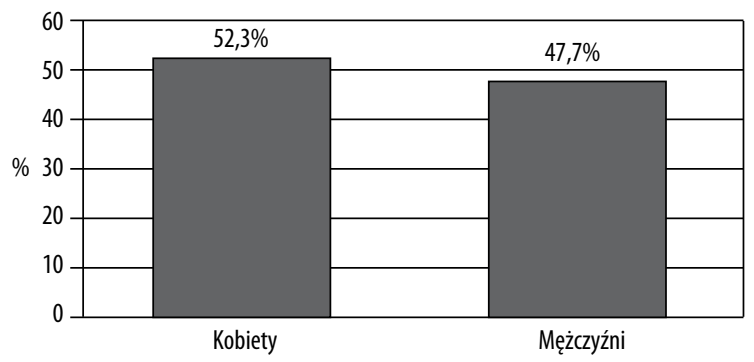

Rycina 1. Struktura płci w grupie badanej

Figure 1. Sex ratio in studied group

1. Sound Effect Recognition Test.

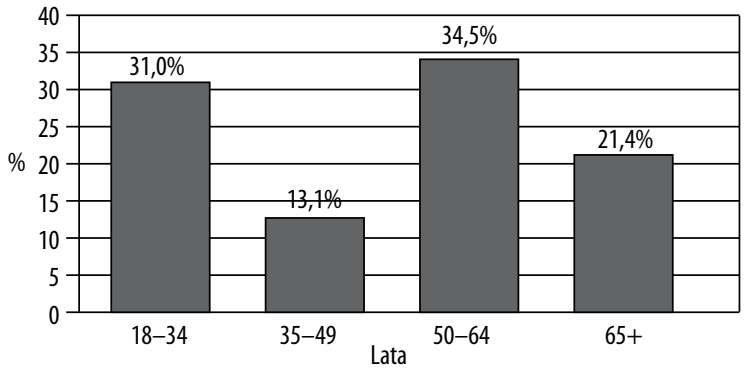

Rycina 2. Struktura wieku w grupie badanej. Odsetek pacjentów w wieku 18-34, 35-49, 50-64 i powyżej 65 lat

Figure 2. Age distribution in studied group. Proportion of patients aged $18-34,35-49,50-64$ and above 65 years

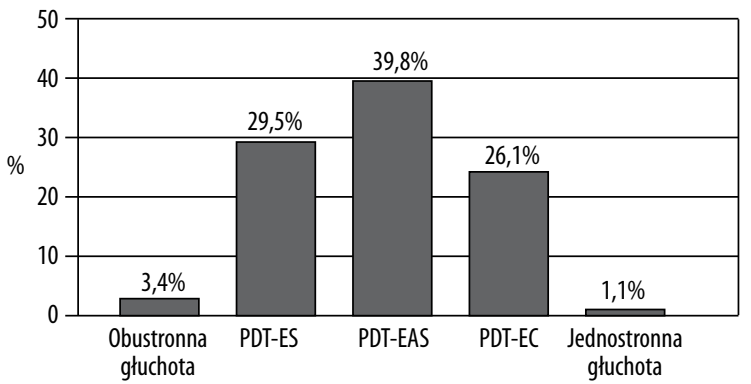

Rycina 3. Podział pacjentów według klasyfikacji Skarżyńskiego Figure 3. Distribution of patients according to Skarżynski's Classification

Osoby z obustronną głuchotą stanowiły 3,4\% pacjentów. Pozostałe 95,5\% stanowili pacjenci z obustronną częściową głuchotą, a 1,1\% - pacjenci z jednostronną głuchotą.

Analizie poddano odpowiedzi pochodzące $\mathrm{z}$ kwestionariusza „Karta dźwięków”, który pacjenci wypełniali przed uruchomieniem systemu implantu i miesiąc po jego aktywacji.

Grupę kontrolną stanowiły 43 osoby dorosłe ze słuchem prawidłowym, które wypełniały tę samą ankietę. Do analizy statystycznej wyników postrzegania dźwięków przed aktywacją i po aktywacji systemu implantu wykorzystano test t-Studenta dla prób zależnych. Za istotne statystycznie przyjmowano wyniki dla poziomu istotności $\mathrm{p}<0,05$.

\section{Wyniki}

Odsetek dźwięków niesłyszanych przez pacjentów przed wszczepieniem implantu ślimakowego wyniósł średnio 31,7\% (rycina 5). Miesiąc po aktywacji wartość ta zmniejszyła się o połowę - do poziomu $15,9 \%$.

Rozkład odpowiedzi na pytanie „Czy słychać?” został przedstawiony z podziałem na siedem kategorii, z których każda odpowiada słyszeniu $14 \%$ dźwięków uwzględnionych w kwestionariuszu. Przed aktywacją CI 29,8\% pacjentów słyszało mniej niż 43\% dźwięków, zaś 24,1\% pacjentów słyszało co najmniej 86\% dźwięków (rycina 6).

Miesiąc po aktywacji ponad $90 \%$ pacjentów słyszało co najmniej 43\% dźwięków. Natomiast 35,6\% wszystkich badanych słyszało co najmniej $86 \%$ dźwięków. 

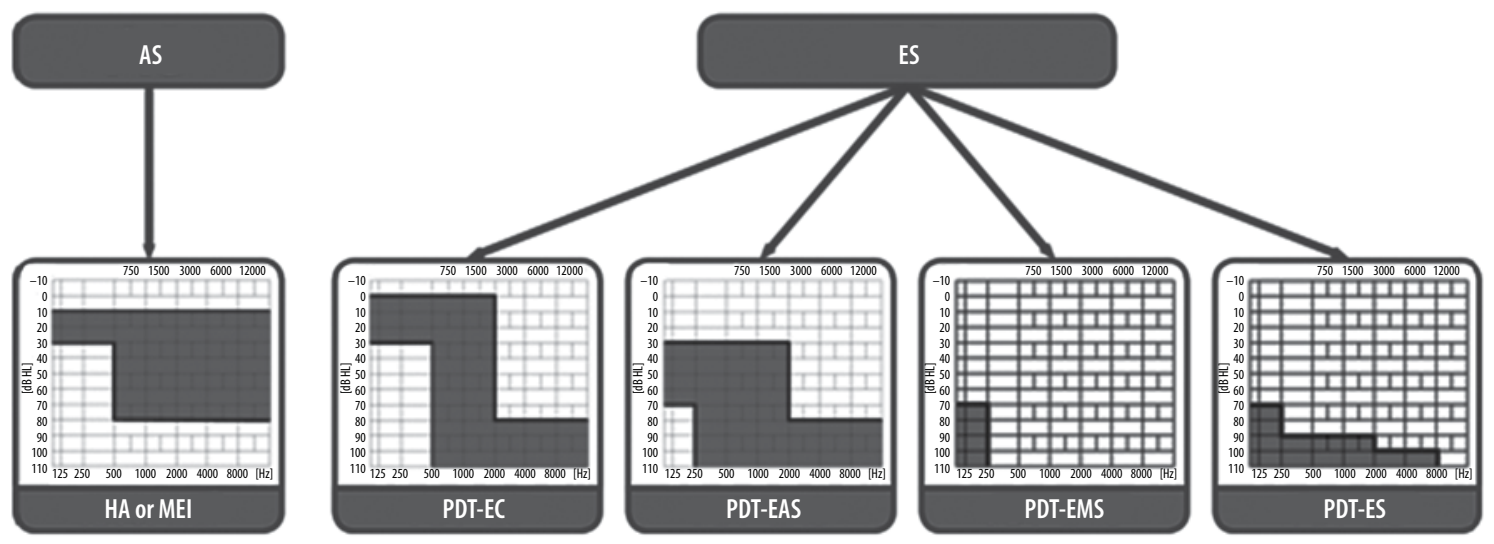

Rycina 4. Klasyfikacja według Skarżyńskiego [20]

Figure 4. Skarzynski's Classification [20]

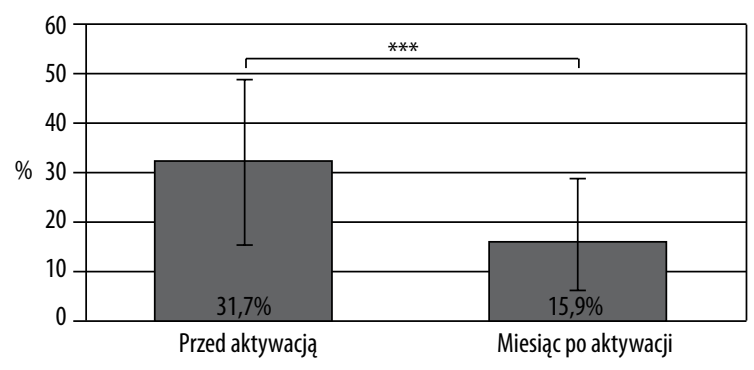

Rycina 5. Średni odsetek niesłyszanych dźwięków przed aktywacją i miesiąc po aktywacji systemu implantu ślimakowego w grupie badanej $(p<0,001)$

Figure 5. Mean proportion of sounds not heard before implant activation and one month after the activation in the studied group $(p<0.001)$

\section{Dyskusja}

Zaprezentowane wyniki świadczą o poprawie postrzegania dźwięków otoczenia już po pierwszym miesiącu użytkowania systemu implantu ślimakowego. Średni procentowy udział dźwięków otoczenia raportowanych przez pacjentów jako niesłyszane zmniejszył się z 31,7\% do 15,9\% dźwięków uwzględnionych w badaniu ankietowym.

Taki odsetek niesłyszanych dźwięków przed aktywacją CI wynika z liczebnej przewagi pacjentów z częściową głuchotą, co odzwierciedla przyjęte obecnie kryteria kwalifikacyjne do wszczepienia implantu. Osoby z obustronną głuchotą oraz z głuchotą jednostronną stanowią odpowiednio $3,4 \%$ i $1,1 \%$ pacjentów w grupie badanej. Pozostali $(95,5 \%)$ to pacjenci z częściową głuchotą.

Poprawa percepcji dźwięków jest również widoczna w zestawieniu wyników przedstawionych na rycinie 7 . Przed

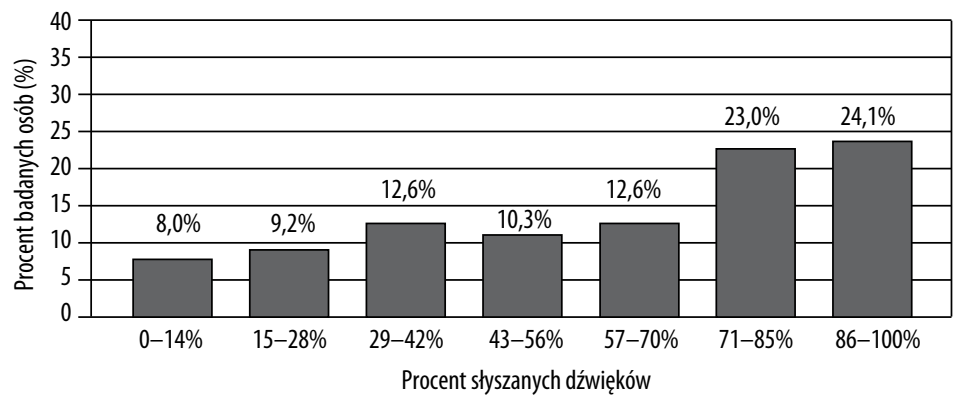

Zmiany w słyszeniu poszczególnych dźwięków przed aktywacją i miesiąc po aktywacji CI zostały przedstawione w tabeli 1.

Zestawienie dźwięków nieprzyjemnych dla użytkowników implantów i grupy z normą słuchową przedstawiono w tabeli 2.
Rycina 6. Odsetek pacjentów słyszących określony procent dźwięków przed aktywacją systemu implantu ślimakowego. Szerokość przedziałów wynika z podzielenia zakresu słyszanych dźwięków $\left(\mathrm{x}_{\min }=0 ; \mathrm{x}_{\max }=21\right)$ przez liczbę przedziałów $\mathrm{K}=7: \Delta=21 / 7=3,(\Delta / \mathrm{n})^{*}$ $100 \%=14 \%$

Figure 6. Proportion of patients hearing a specified percentage of sounds before the activation of the cochlear implant system. The width of intervals results from the devision of the range of audible sounds $(x \min =0$; $x \max =21$ ) by the number of intervals $K=7$ : $\Delta=21 / 7=3,(\Delta / n)^{*} 100 \%=14 \%$ 
Tabela 1. Odsetek pacjentów słyszących poszczególne dźwięki z karty dźwięków przed aktywacją i po aktywacji systemu implantu ślimakowego

Table 1. Sounds heard before and one month after the activation of the cochlear implant system. Bold numbers indicate most frequently heard sounds, italics - least frequently heard sounds

\begin{tabular}{|c|c|c|}
\hline & \multicolumn{2}{|c|}{ Słyszane dźwięki } \\
\hline & $\begin{array}{c}\text { Przed } \\
\text { aktywacją }\end{array}$ & $\begin{array}{l}\text { Miesiąc po } \\
\text { aktywacji }\end{array}$ \\
\hline odkurzacz & $81 \%$ & $89 \%$ \\
\hline śpiew ptaków & $52 \%$ & $64 \%$ \\
\hline odgłos sztućców & $68 \%$ & $91 \%$ \\
\hline samolot & $57 \%$ & $57 \%$ \\
\hline suszarka do włosów & $72 \%$ & $85 \%$ \\
\hline płynąca woda z kranu & $59 \%$ & $85 \%$ \\
\hline karetka pogotowia & $86 \%$ & $92 \%$ \\
\hline płacz dziecka & $76 \%$ & $72 \%$ \\
\hline burza z piorunami & $74 \%$ & $61 \%$ \\
\hline szelest reklamówki & $53 \%$ & $78 \%$ \\
\hline tykanie zegara & $35 \%$ & $55 \%$ \\
\hline czajnik z gwizdkiem & $67 \%$ & $70 \%$ \\
\hline spuszczanie wody w toalecie & $75 \%$ & $94 \%$ \\
\hline stukanie obcasów & $70 \%$ & $86 \%$ \\
\hline pisk opon samochodu & $80 \%$ & $78 \%$ \\
\hline szelest kartek papieru & $48 \%$ & $78 \%$ \\
\hline szczekanie psa & $86 \%$ & $93 \%$ \\
\hline cięcie papieru nożyczkami & $26 \%$ & $56 \%$ \\
\hline hałas uliczny & $73 \%$ & $91 \%$ \\
\hline $\begin{array}{l}\text { odgłos kierunkowskazu } \\
\text { samochodu }\end{array}$ & $36 \%$ & $56 \%$ \\
\hline szum gotującej się wody & $44 \%$ & $60 \%$ \\
\hline
\end{tabular}

Tabela 2. Odsetek osób, które określały dźwięki jako nieprzyjemne, z podziałem na osoby z normą słuchową oraz pacjentów przed aktywacją systemu implantu ślimakowego i pacjentów korzystających z implantu od miesiąca Table 2. Proportion of persons who described sounds as unpleasant divided into normal hearing persons, patients before the activation of the cochlear implant system and patients one month after activation

\begin{tabular}{lccc}
\hline & \multicolumn{3}{c}{ Nieprzyjemne dźwięki } \\
\cline { 2 - 4 } & $\begin{array}{c}\text { Norma } \\
\text { słuchowa }\end{array}$ & $\begin{array}{c}\text { Przed } \\
\text { aktywacją }\end{array}$ & $\begin{array}{c}\text { Miesiąc po } \\
\text { aktywacji }\end{array}$ \\
\hline odkurzacz & $37 \%$ & $34 \%$ & $29 \%$ \\
\hline śpiew ptaków & $16 \%$ & $14 \%$ & $\mathbf{5 \%}$ \\
\hline odgłos sztućców & $28 \%$ & $43 \%$ & $50 \%$ \\
\hline samolot & $35 \%$ & $25 \%$ & $15 \%$ \\
\hline suszarka do włosów & $40 \%$ & $21 \%$ & $18 \%$ \\
\hline płynąca woda z kranu & $14 \%$ & $11 \%$ & $11 \%$ \\
\hline karetka pogotowia & $58 \%$ & $42 \%$ & $58 \%$ \\
\hline płacz dziecka & $51 \%$ & $41 \%$ & $44 \%$ \\
\hline burza z piorunami & $23 \%$ & $32 \%$ & $21 \%$ \\
\hline szelest reklamówki & $28 \%$ & $48 \%$ & $48 \%$ \\
\hline tykanie zegara & $23 \%$ & $15 \%$ & $\mathbf{5 \%}$ \\
\hline czajnik z gwizdkiem & $49 \%$ & $39 \%$ & $43 \%$ \\
\hline $\begin{array}{l}\text { spuszczanie wody } \\
\text { w toalecie }\end{array}$ & $21 \%$ & $11 \%$ & $22 \%$ \\
\hline stukanie obcasów & $16 \%$ & $37 \%$ & $37 \%$ \\
\hline pisk opon samochodu & $56 \%$ & $42 \%$ & $64 \%$ \\
\hline szelest kartek papieru & $\mathbf{1 2 \%}$ & $18 \%$ & $9 \%$ \\
\hline szczekanie psa & $37 \%$ & $29 \%$ & $38 \%$ \\
\hline $\begin{array}{l}\text { cięcie papieru } \\
\text { nożyczkami }\end{array}$ & $\mathbf{1 2 \%}$ & $0 \%$ & $14 \%$ \\
\hline hałas uliczny & $51 \%$ & $53 \%$ & $32 \%$ \\
\hline $\begin{array}{l}\text { odgłos } \\
\text { kierunkowskazu sam. }\end{array}$ & $\mathbf{7 \%}$ & $\mathbf{0 \%}$ & $\mathbf{0 \%}$ \\
\hline $\begin{array}{l}\text { szum gotującej się } \\
\text { wody }\end{array}$ & $\mathbf{9 \%}$ & $\mathbf{7 \%}$ & $13 \%$ \\
\hline
\end{tabular}

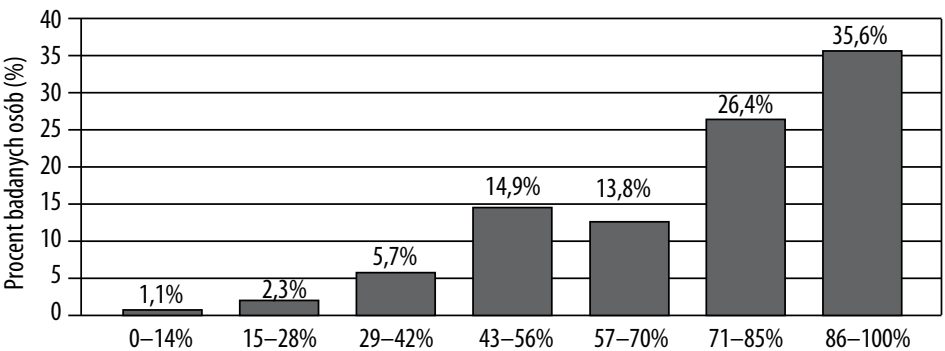

Procent słyszanych dźwięków
Rycina 7. Odsetek pacjentów słyszących określony procent dźwięków po aktywacji systemu implantu ślimakowego. Szerokość przedziatów wynika z podzielenia zakresu słyszanych dźwięków $\left(x_{m i n}=0 ; x_{m a x}=21\right)$ przez liczbę przedziałów $K=7: \Delta=21 / 7=3,(\Delta / n)^{\star} 100 \%=14 \%$

Figure 7. Proportion of patients hearing a specified percentage of sounds after the activation of the cochlear implant system. The width of intervals from results the devision at the range of audible sounds $(x \min =0$; $x \max =21$ ) by the number of intervals $\mathrm{K}=7$ : $\Delta=21 / 7=3,(\Delta / n)^{*} 100 \%=14 \%$
Z przeprowadzonych badań wynika, że przed aktywacją systemu CI najrzadziej zgłaszano postrzeganie takich dźwięków jak: cięcie papieru nożyczkami, tykanie zegara, odgłos kierunkowskazu samochodu, szum gotującej się wody, szelest kartek papieru. Problemy z postrzeganiem wymienionych wyżej dźwięków przez większość pacjentów 


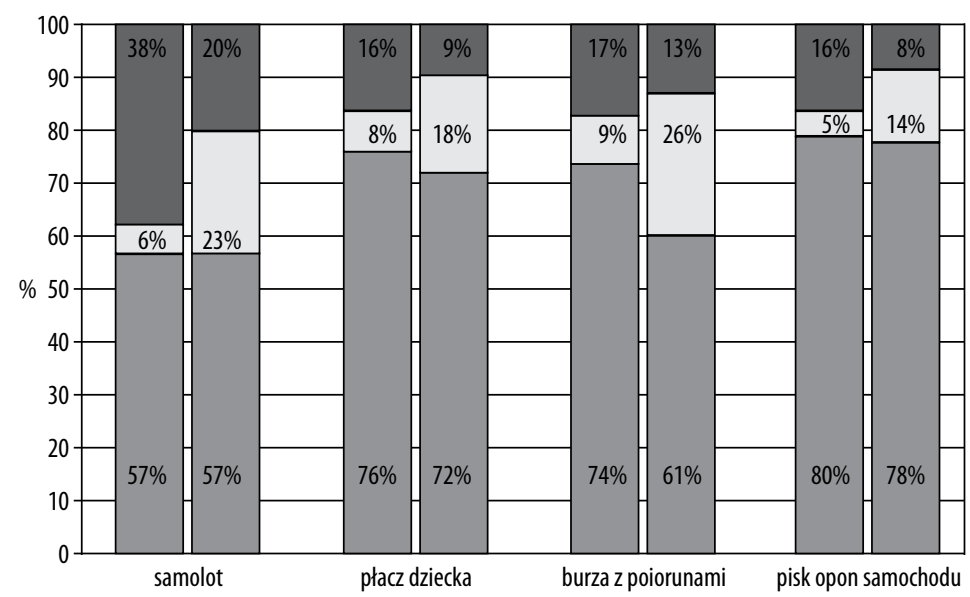

Tak $\square$ Nie miałem(am) okazji sprawdzić $\square$ Nie
Rycina 8. Odsetek odpowiedzi „tak”, „nie miałam/em okazji sprawdzić” i „nie”. Analiza odpowiedzi na pytanie „Czy słychać?” dla dźwięków, dla których liczba odpowiedzi „tak” nie zwiększyła się w interwale - miesiąc po aktywacji systemu implantu ślimakowego. W pierwszej kolumnie dla każdego dźwięku zaznaczono wyniki przed aktywacją, w drugiej wyniki miesiąc po aktywacji systemu implantu ślimakowego

Figure 8. Proportion of responses 'yes', „I had no occasion to check' and 'no'. Analysis of responses to question 'Can you hear?' for sounds, where the number of responses 'YES' did not increase in one-month interval after the cochlear implant activation. The first column includes scores for each sound before the activation, second - one month after the activation of the cochlear implant system związane są z ich charakterystyką akustyczną. Poziom natężenia tych dźwięków występujących w krajobrazie akustycznym jest mały. Ponadto przebieg widma gęstości mocy jest wysokoczęstotliwościowy, a u większości pacjentów wartość audiometrycznego progu słyszenia w obojgu uszach wskazywała głęboki ubytek słuchu dla wysokich częstotliwości. Miesiąc po aktywacji odsetek pacjentów raportujących postrzeganie tych dźwięków wzrósł znacząco: cięcie papieru nożyczkami - o 30 punktów procentowych; tykanie zegara - o 20 punktów procentowych; odgłos kierunkowskazu samochodu - o 20 punktów procentowych; szum gotującej się wody - o 16 punktów procentowych; szelest kartek papieru - o 30 punktów procentowych. Poprawa postrzegania tych dźwięków już miesiąc po aktywacji systemu implantu ślimakowego wskazuje na to, że implant pozwala na szybką i skuteczną kompensację uszkodzonych funkcji percepcyjnych układu słuchowego. Do najczęściej postrzeganych dźwięków przed aktywacją systemu należały: szczekanie psa, karetka pogotowia, odkurzacz, pisk opon samochodu, płacz dziecka. Postrzeganie ich raportowało odpowiednio 93\%, 92\%, 89\%, 80\% oraz $76 \%$ pacjentów. Stosunkowo dobrą percepcję tych dźwięków przez kandydatów do implantu ślimakowego można wytłumaczyć dużym poziomem natężenia akustycznego tych dźwięków.

Analizując uzyskane wyniki, stwierdzono, że dla części dźwięków (samolot, płacz dziecka, burza z piorunami, pisk opon samochodu) nie wystąpiła poprawa w ich postrzeganiu po wszczepieniu implantu. Wyniki badania ankietowego przedstawione na rycinie 8 wskazują na to, że brak mierzalnej poprawy postrzegania tych dźwięków wynika $\mathrm{z}$ faktu, iż znaczna liczba osób zadeklarowała brak możliwości sprawdzenia w ciągu miesiąca od aktywacji, czy słyszy te dźwięki. Na rycinie 8 widać jednocześnie, że zmniejszyła się liczba osób, które deklarują, że nie słyszą wymienionych dźwięków. W związku z tym trudno jest ocenić, czy postrzeganie tych dźwięków uległo poprawie.

$\mathrm{W}$ przeprowadzonych badaniach oceniany był również aspekt estetyczny postrzegania dźwięków otoczenia. Wyniki tej oceny zamieszczono w tabeli 2. Dźwięki wymieniane najrzadziej jako nieprzyjemne przez osoby przed aktywacją systemu implantu ślimakowego to: cięcie papieru, odgłos kierunkowskazu oraz szum gotującej się wody. Dźwięki te w typowym krajobrazie akustycznym charakteryzują się bardzo małym poziomem natężenia. Warto zauważyć, że z tego samego powodu ww. dźwięki są najtrudniejsze w odbiorze dla osób przed aktywacją implantu. Dźwięki oceniane przez tę grupę pacjentów jako najbardziej nieprzyjemne to: hałas uliczny, szelest reklamówki i odgłos sztućców. Po aktywacji CI dźwięki najrzadziej oceniane jako nieprzyjemne to: odgłos kierunkowskazu, śpiew ptaków oraz tykanie zegara. Natomiast osoby korzystające z CI od miesiąca najczęściej uznawały za nieprzyjemne następujące dźwięki: pisk opon, karetkę pogotowia i odgłos sztućców. To samo pytanie zostało zadane osobom ze słuchem prawidłowym. W tej grupie osób za nieprzyjemne najczęściej uznane zostały następujące dźwięki: karetka pogotowia, pisk opon, płacz dziecka i hałas uliczny. Do dźwięków najrzadziej uznawanych za nieprzyjemne należały: odgłos kierunkowskazu, szum gotującej się wody, szelest kartek papieru i cięcie papieru, podobnie jak w przypadku osób przed aktywacją CI. Odpowiedzi osób implantowanych dotyczące dźwięków uznanych za najbardziej nieprzyjemne, tj. karetki pogotowia i hałasu ulicznego, pokrywają się zatem z odpowiedziami osób ze słuchem prawidłowym. U pacjentów będących miesiąc po aktywacji systemu implantu ślimakowego nie zaobserwowano znacznych, ilościowych zmian w odbiorze dźwięków nieprzyjemnych.

Potwierdza to zasadność stosowanej w IFPS strategii ustawiania procesora dźwięku, która ma służyć przygotowaniu pacjentów z systemem implantu ślimakowego do przebywania w środowisku zróżnicowanym akustycznie. Parametry stymulacji są tak dobierane, aby stopniowo zwiększać obciążenie drogi słuchowej, dopasowując je do indywidualnych możliwości pacjenta. Komfort przebywania w otoczeniu jest wówczas nie mniejszy niż ten, który odczuwa osoba słysząca w normie.

Z przeglądu literatury poświęconej postrzeganiu dźwięków przez osoby implantowane wynika, że większość badań 
dotyczyła dźwięków mowy albo identyfikacji dźwięków otoczenia w testach zamkniętych. Wśród nielicznych badań dotyczących spostrzegania dźwięków otoczenia możemy wyróżnić badania Tylera [7].

Tyler, korzystając z badań kwestionariuszowych, przebadał 53 pacjentów, którzy odpowiadali na pytania dotyczące korzyści i utrudnień wynikających z używania CI. W badaniach tych poprawę postrzegania dźwięków otoczenia zgłosiło $75 \%$ osób. W badaniach przeprowadzonych w IFPS było to odpowiednio 58,6\%. U Tylera jako zysk z implantu 7,5\% badanych wskazało lepsze postrzeganie sygnałów alarmowych, a 5,7\% - śpiewu ptaków. W naszych badaniach, po miesiącu używania implantu odsetek pacjentów słyszących syreny karetki pogotowia oraz śpiew ptaków wzrósł odpowiednio z $86 \%$ do $92 \%$ oraz z 52\% do $64 \%$ $\mathrm{w}$ porównaniu ze stanem sprzed aktywacji. Według obu prac badawczych nastąpiła poprawa w odbiorze dźwięków.

Należy jednak zaznaczyć różnicę w przeprowadzonych badaniach. Tyler przebadał grupę pacjentów średnio po dwóch latach użytkowania implantu (bez podziału na interwały), którzy uzyskali najlepsze wyniki w teście percepcji mowy. Wykorzystał do tego kwestionariusz pytań otwartych. W IFPS przebadano pacjentów miesiąc po aktywacji CI, a jedynym kryterium doboru pacjentów był wiek (przebadano osoby powyżej 18 roku życia), bez względu na wyniki innych testów. W badaniu użyto narzędzia $z$ pytaniami zamkniętymi. Badania Tylera dotyczyły pacjentów, którzy zakwalifikowani byli na podstawie kryteriów kwalifikacji obowiązujących w latach 90 . Byli to zatem pacjenci z całkowitą głuchotą. W naszym badaniu 96,6\% pacjentów to osoby $\mathrm{z}$ częściową lub jednostronną głuchotą.

U Tylera jako przyczynę dyskomfortu 15\% badanych wskazało dźwięki otoczenia takie jak: odgłos samolotu, hałas uliczny, gwałtownie płynąca woda (jedyne dźwięki wspólne dla obu badań). Natomiast w naszych badaniach dźwięki te uznało za nieprzyjemne odpowiednio 15\%, 22\% i 32\% osób.

Kowalczyk badała ocenę dźwięków obecnych w różnych typach krajobrazu na populacji osób słyszących, wielu narodowości [16]. Za najbardziej przyjemny dźwięk otoczenia uznany został śpiew ptaków. Źródłami nieprzyjemnych dźwięków może być komunikacja miejska, ogólnie hałas miejski i sprzęt techniczny oraz "groźne” dla życia zjawiska atmosferyczne. W badaniach przeprowadzonych przez Kowalczyk hałas uliczny był nieprzyjemny dla 55\% badanych (badania dotyczące narodowości polskiej), w naszym badaniu dla 51\%. Wyniki badań dla osób z normą słuchową przeprowadzonych przez Kowalczyk są zatem zbieżne $\mathrm{z}$ wynikami uzyskanymi w grupie osób implantowanych.

\section{Wnioski}

W pracy wykazano, że:

1. Część dźwięków otoczenia postrzegana jest przez większość pacjentów przed aktywacją systemu implantu ślimakowego.

2. Postrzeganie dźwięków otoczenia przez pacjentów ulega poprawie już po upływie miesiąca od aktywacji CI.

3. Efekt estetyczny tych dźwięków nie pogarsza się po aktywacji CI, jak również liczba dźwięków percypowanych jako nieprzyjemne przez pacjentów po aktywacji CI nie ulega istotnym zmianom $\mathrm{w}$ porównaniu $\mathrm{z}$ doświadczeniami przed implantacją.

4. Ocena estetyki odbieranych dźwięków otoczenia w kategorii przyjemny/nieprzyjemny po aktywacji CI jest podobna do oceny dokonanej przez osoby prawidłowo słyszące.

Projekt został sfinansowany ze środków Narodowego Centrum Nauki przyznanych na podstawie decyzji nr DEC-2013/09/B/ ST7/04213.

\section{Piśmiennictwo:}

1. Bernat S. Metody badań krajobrazowych dźwiękowych. W: Dźwięk w krajobrazie jako przedmiot badań interdyscyplinarnych. Instytut Nauk o Ziemi UMCS, Prace Komisji Krajobrazu Kulturowego PTG, 2008; 11: 122-33.

2. Ozimek E. Dźwięk i jego percepcja. Aspekty fizyczne i psychoakustyczne. Warszawa - Poznań: PWN; 2002.

3. Skrodzka E, Sęk A, Marszałkiewicz M. Psychakustyka w pigułce. Poznań: UAM; 2000.

4. Misiak T. Od przestrzeni akustycznej do akustycznej cyberprzestrzeni. Słyszenie w refleksji filozoficznej a muzyka elektroniczna. Poznań; 2007; dostępne na stronie: http://kaleka.net/files/od_ przestrzeni_akustycznej_do_akustycznej_cyberprzestrzeni.\%20 doc

5. Jenkins JJ. Acoustic information for objects, places, and events. W: Warren WH, Shaw RE, red. Persistence and change: Proceedings of the first international conference on event perception. NJ; 1985.

6. Olszewska M. Słuchanie, które powołuje do istnienia. Wokół koncepcji Deep Listening Pauline Oliveros. Instytut Nauk o Ziemi UMCS, Prace Komisji Krajobrazu Kulturowego PTG, 2008; 11: 315-9.
7. Tyler R, Kelsay D. Advantages and disadvatages reported by some of the better cochlear-implant patiens. Am J Otol, 1990; 11(4): 282-9.

8. Lachowska M, Różycka J, Łukaszewicz Z, Konecka A, Niemczyk K. Ocena rozwoju postępów słuchowych i językowych po wszczepieniu implantu ślimakowego u dzieci z dodatkowymi obciążeniami. Otolaryngol Pol, 2010; 64(7): 22-6.

9. Inverso Y, Limb CJ. Cochlear implant-miediated perception of nonlingustic sounds. Ear Hear, 2010; 31(4): 505-14.

10. Gygi B. Factors in the identification of environmental sounds. Submitted to the faculty of the university graduate school in partial fulfillment of the requirements for the degree doctor of philosophy in the department of psychology. Indiana University; 2001.

11. Goldhor SR. Recognition of environmental sounds. Acoustics, Speech, and Signal Processing, 1993; 1: 149-52.

12. Bernat S. Dźwięk i muzyka w krajobrazie. W: Strzyż M, red. Perspektywy rozwoju regionu w świetle badań krajobrazowych. Kielce: Problemy Ekologii Krajobrazu PAEK; 2004, 289-95.

13. Lewis JW, Wightman FL, Brefczynski JA, Phinney RE, Binder JR, DeYoe EA. Human brain regions involved in recognizing environmental sounds. Cereb Cortex, 2004; 14(9): 1008-21. 
14. Reed CM, Delhorne LA. Reception of environmental sounds through cochlear implants. Ear Hear, 2005; 26(1): 48-61.

15. Geremek-Samsonowicz A, Kłonica LK, Rostowska J, Piełuć M, Skarżyński H. Model postępowania diagnostyczno-terapeutycznego. Nowa Audiofonologia, 2012; 1(1): 119-25.

16. Kowalczyk A. Preferencje dźwięków w krajobrazie. W: Dźwięk w krajobrazie jako przedmiot badań interdyscyplinarnych. Instytut Nauk o Ziemi UMCS, Prace Komisji Krajobrazu Kulturowego PTG, 2008; 11: 36-43.

17. Łukomska A, Wileńska $\mathrm{N}$. Wpływ określonych rodzajów podkładu dźwiękowego na ocenę przyjemności, wynikającej z prezentacji różnych kategorii krajobrazów. Dostępne na stronie: www.staff.amu.edu.pl/ justynam/WilenskaLukomska.pdf

18. Lerch M, Decker-Maruska M. The importance of hearing for older adults: A geriatrician's perspective. Journal of Hearing Science, 2012; 2(4): 40-42.

19. Czapiński J. Psychologiczne teorie szczęścia. W: Czapiński J, red. Psychologia pozytywna. Nauka o szczęściu, zdrowiu, sile i cnotach człowieka. Warszawa: PWN; 2004, 51-102.

20. Skarżyński H, Lorens A, Piotrowska A, Skarżyński PH. Hearing preservation in partial deafness treatment. Med Sci Monit, 2010; 16(11): 555-62.

21. Zhao F, Stephens SDG, Sim SW, Meredith R. The use of qualitative questionnaires in patients having and being considered for cochlear implants. Clin Otolaryngol, 1997; 11(3): 254-59.
22. Shafiro V, Gygi B, Cheng MY, Vachhani J, Mulvey M. Perception of environmental sounds by experienced cochlear implant patients. Ear Hear, 2011; 32(4): 511-23.

23. Ballas J. Interpreting the language of environmental sounds, environment and behavior. Sage Publications, 1987; 1(1): 91-114.

24. Shu-Yu Liu, Tien-Chen Liu, Ya-Ling Teng, Li-Ang Lee, Te-Jen Lai, Che-Ming Wu. Environmental sounds recognition in children with cochlear implants. PLoS One, 2013; 8(6): e66100.

25. Shafiro V, Sheft S, Gygi B, Ho KT. The influence of environmental sound training on the perception of spectrally degraded speech and environmental sounds. Trends Amplif, 2012; 16(2): 83-101.

26. Lorens A, Zgoda M, Skarżyński H. A new audio processor for combined electric and acoustic stimulation for the treatment of partial deafness. Acta Otolaryngol, 2012; 132(7): 739-50.

27. Nowak S. Metodologia badań socjologicznych. Warszawa: PWN; 1985.

28. Łobocki M. Metody i techniki badań pedagogicznych. Warszawa: PWN; 1978.

29. Pilch T, Bauman T. Zasady badań pedagogicznych. Warszawa: Żak; 2001.

30. Finitzo-Hieber T, Gerling IJ, Matkin ND, Cherow-Skalka E. A sound effects recognition test for the pediatric audiological evaluation. Ear Hear, 1980; 1: 271-6. 